\title{
Portal Pressure Regulation following Kupffer Cell Activation: Control of Prostaglandin Production by Heme Oxygenases
}

\author{
Christian J. Steib ${ }^{a}$ Leonore Gmelin ${ }^{a}$ Manfred Bilzer ${ }^{b}$ Burkhard Göke ${ }^{a}$ \\ Alexander L. Gerbes ${ }^{\text {a }}$ \\ ${ }^{a}$ Department of Medicine II, University of Munich, Klinikum Grosshadern, Munich, and ${ }^{\mathrm{b}}$ MSD, Haar, Germany
}

\section{Key Words}

Kupffer cell $\cdot$ Nitric oxide $\cdot$ Carbon monoxide $\cdot$ Portal

hypertension $\cdot$ Microcirculation

\begin{abstract}
Background: Portal pressure (PP) results from the interplay of vasoconstrictors and vasodilators. Recently, we have shown that Kupffer cell (KC) activation increases PP. Aims: The role of the vasodilating compounds nitric oxide (NO) and carbon monoxide (CO) was studied. The hypothesis of the present study was that these vasodilators counteract the PP increase following KC activation. Methods: Livers of rats weighing $180-200 \mathrm{~g}$ were isolated and perfused. KCs were activated by zymosan $A$ (cell wall particles from yeast; 150 $\mu \mathrm{g} / \mathrm{ml})$. The effects of NO and guanylate cyclase (GC) were evaluated by the NO synthase inhibitor $\mathrm{N}^{G}$-nitro-L-arginine methylester (L-NAME; $0.3 \mathrm{~mm}$, and the GC inhibitor 4H-8-bromo-1,2,4-oxadiazolo(3,4-d)benz(b)(1,4)oxazin-1one (NS-2028, $1.0 \mu \mathrm{M})$; the effects of the heme oxygenase (HO) derived compound $\mathrm{CO}$ were evaluated by direct administration of $\mathrm{CO}$ or inhibition of $\mathrm{HO}$ by zinc protoporphyrin IX (ZnPP IX, $1.0 \mu \mathrm{M})$. Results: In isolated perfused rat livers, administration of L-NAME or NS-2028 further raised PP increase following $\mathrm{KC}$ activation. This effect could be reduced by the
\end{abstract}

cGMP analogue 8-Br-cGMP. Inhibition of HO caused marked amplification of PP increase in zymosan-treated organs. CO prevented this PP increase CGMP independently. Interestingly, KC activation and simultaneous inhibition of $\mathrm{HO}$ augmented the production of prostaglandins $\mathrm{D}_{2}$ and $\mathrm{F}_{2} \alpha$ and of thromboxane $A_{2}$. Accordingly, indomethacin blunted the increase of PP in zymosan/ZnPP-treated livers. Conclusions: NO restricts the initial PP increase after KC activation by GCmediated CGMP. CO from heme degradation limits the increase of PP after KC activation eicosanoid dependently, but cGMP independently.

Copyright $\odot 2013$ S. Karger AG, Basel

\section{Introduction}

Liver function is dependent on intrahepatic microcirculation. It has been shown that Kupffer cell (KC) activation affects the microcirculation of the liver [1-7]. The involved mechanisms are an increased production of vasoconstrictors [8-12], enhanced responsiveness to vasoconstrictors [13-15] and an altered production of vasodilators [16-20]. The best known vasoconstrictors are prostaglandins (PGs) such as thromboxane (TX) $\mathrm{A}_{2}$ and cysteinyl leukotrienes like leukotriene $\mathrm{C}_{4}$ and $\mathrm{D}_{4}[6,9]$; to 
the relevant vasodilators account nitric oxide (NO) and carbon monoxide (CO) [21-25].

KCs produce a significant amount of vasoconstrictors [11], which act on the contractile cells in the liver which are hepatic stellate cells and myofibroblasts $[13,26]$. Contraction mechanisms are under the control of $\mathrm{Ca}^{2+}$-dependent and $\mathrm{Ca}^{2+}$-independent pathways [27].

The vasodilator $\mathrm{NO}$ is generated by different nitric oxide synthases (NOS). The constitutively expressed isoform endothelial NOS (eNOS) seems to be involved in the physiological regulation of hepatic perfusion [28]. For vasodilation, NO stimulates the soluble guanylate cyclase (GC) to produce cyclic guanosine monophosphate (cGMP) in vascular smooth muscle cells [29]. CO is produced by the degradation from protoheme IX to biliverdin. This step is catalyzed by heme oxygenases $(\mathrm{HO})$ which are found in the liver in two different isoforms, the inducible isoform $\mathrm{HO}-1$ and the constitutive isoform HO-2. In normal livers HO-2 influences the hepatic microcirculation. This has been shown by investigations with the HO inhibitor ZnPP IX [22].

$\mathrm{KC}$ activation has been found to influence hepatic microcirculation in normal livers [5]. To date, the mechanisms which counteract this portal pressure (PP) increase are not well defined. Here, we investigated the effects of $\mathrm{NO}$ and $\mathrm{CO}$ following $\mathrm{KC}$ activation in normal livers utilizing an in vitro model with the potential to better understand the clinical situation. The restriction of PP increase following $\mathrm{KC}$ activation is of clinical importance in healthy livers. These mechanisms and their therapeutic intervention possibilities are responsible to limit the deleterious effects of microcirculatory disturbances in liver injury, liver failure or following liver transplantation [30-33].

\section{Materials and Methods}

\section{Animal Studies}

Animals were ethically treated according to the criteria established by the National Academy of Sciences and published by the National Institutes of Health, in addition to the legal requirements of Germany. All animal experiments were approved by the local government (Regierung von Oberbayern, Munich, Germany) and were reported to the responsible authorities.

\section{In situ Rat Liver Perfusion Study}

Male Sprague-Dawley rats (180-200 g; Charles River, Sulzfeld, Germany) were anesthetized by intraperitoneal injection of sodium pentobarbital (50 mg/kg b.w.). After incision of the abdominal wall, the portal vein was cannulated with a 14-gauge Teflon intravenous catheter, and the liver was perfused at a constant flow rate. The inferior vena cava was cannulated through the right atri- um and ligated above the right renal vein. For all experiments, the

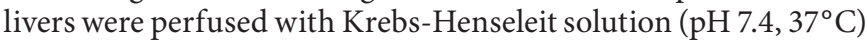
in a non-recirculating manner. The perfusion buffer was gassed with a mixture of $95 \% \mathrm{O}_{2}$ and $5 \% \mathrm{CO}_{2}$ using an oxygenator [34]. The portal perfusion pressure (PPP) was monitored continuously. The bile duct was cannulated with polyethylene tubing (PE10) in order to monitor bile flow. The liver was allowed to stabilize for 25 min prior to the addition of any substances. During this initial 25-min stabilization period, liver viability was determined using two criteria: (1) the maintenance of stable perfusion pressure and (2) lactate dehydrogenase efflux rates of $<10 \mathrm{mU} / \mathrm{min} \cdot \mathrm{g}$ of liver. Lactate dehydrogenase activity was analyzed as reported elsewhere [5]. If one of the criteria for viability was not satisfied, the experiment was discarded.

\section{KC Activation}

Control experiments using Krebs-Henseleit buffer were performed over a 100 -min time period $(n=6)$. To activate KCs, $z y-$ mosan A (cell wall particles from yeast; $150 \mu \mathrm{g} / \mathrm{ml}$, during min $40-46$ after initiating perfusion, $\mathrm{n}=11$ ) was infused into the livers as described previously [11].

\section{Infusion of NO, GC and cGMP}

Rat livers were perfused with Krebs-Henseleit buffer alone for control experiments $(\mathrm{n}=6)$ and zymosan $(\min 40-46,150 \mu \mathrm{g} / \mathrm{ml}$, $\mathrm{n}=11$ ) was infused for KC activation. To inhibit NOS, $\mathrm{N}^{\mathrm{G}}$-nitroL-arginine methylester (L-NAME; $\min 30-100,0.3 \mathrm{mM}, \mathrm{n}=5$ ) was infused additionally. Alternatively, for inhibition of GC, $4 \mathrm{H}$ 8-bromo-1,2,4-oxadiazolo(3,4-d)benz(b)(1,4)oxazin-1-one (NS2028; $\min 30-100,1.0 \mu \mathrm{M}, \mathrm{n}=5$ ) was administered. The cGMP analogue 8 -Br-cGMP (min 30-100, $50 \mu \mathrm{M})$ was infused in combination with L-NAME (min 30-100, $0.3 \mathrm{mM}$ ) and zymosan A (min $40-46,150 \mu \mathrm{g} / \mathrm{ml}, \mathrm{n}=5)$, NS-2028 (min 30-100, $1.0 \mu \mathrm{M})$ and zymosan A ( $\min 40-46,150 \mu \mathrm{g} / \mathrm{ml}, \mathrm{n}=5$ ) or in combination with zymosan A (min 40-46, $150 \mu \mathrm{g} / \mathrm{ml}, \mathrm{n}=5$ ) alone.

\section{Effects of HO on $\mathrm{CO}$ and $c G M P$}

To investigate mechanisms following $\mathrm{KC}$ activation and inhibition of $\mathrm{HO}$, livers were perfused with zymosan $(150 \mu \mathrm{g} / \mathrm{ml})$ from 40 to 46 min together with ZnPP IX $(\min 30-60,1 \mu \mathrm{M}, \mathrm{n}=$ $5)$ and in comparison $\mathrm{ZnPP}$ IX alone ( $\min 30-60,1 \mu \mathrm{M}, \mathrm{n}=5$ ). Additionally, $\mathrm{CO}(2.5 \mu \mathrm{M}, \mathrm{n}=5)$ was infused from min 30 to 100 in order to mimic $\mathrm{HO}$-dependent $\mathrm{CO}$ formation. $\mathrm{CO}$ solutions were prepared as described by Wang [35]: $250 \mathrm{ml} \mathrm{NaCl} 0.9 \%$ was gassed for $15 \mathrm{~min}$ via frit. Saturated CO solutions were infused by microinfusion pumps reaching a final concentration of $2.5 \mu \mathrm{M}$ in the effluent perfusate [21]. The hypothesis whether $\mathrm{CO}$ acts via cGMP was tested by additional infusion of 8 - $\mathrm{Br}-\mathrm{cGMP}$ instead of $\mathrm{CO}(\min 30-100,50 \mu \mathrm{M}, \mathrm{n}=5)$.

\section{PG Production and Its Functional Role}

Production of the $\mathrm{PGD}_{2}, \mathrm{PGF}_{2} \alpha$ and TXA 2 was quantified by their release into perfusate. $\mathrm{PGD}_{2}$ and $\mathrm{TXB}_{2}$, the stable degradation product of $\mathrm{TXA}_{2}$, was measured in duplicate using radioimmunoassays (Amersham, Freiburg, Germany). $\mathrm{PGF}_{2} \alpha$ was measured by an enzyme immunoassay (Assay Designs, Inc., Ann Arbor, Mich., USA). To delineate the functional role of PGs, the cyclooxygenase (COX)-1/COX-2 inhibitor indomethacin (min $30-60,50 \mu \mathrm{M}, \mathrm{n}=5$ ) was infused in combination with zymosan $(\mathrm{min} 40-46,150 \mu \mathrm{g} / \mathrm{ml})$ and $\mathrm{ZnPP}$ IX (min 30-60, $1 \mu \mathrm{M})$. 


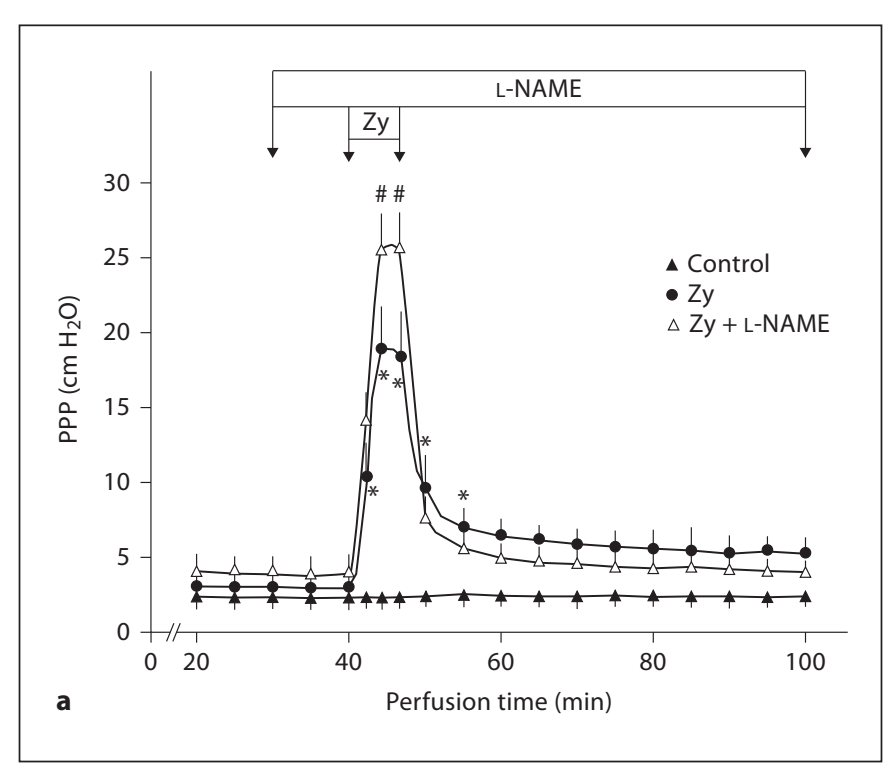

Fig. 1. Increase of PPP following KC activation and effects of NOS. a KCs were activated by administration of zymosan $(Z y, 150 \mu \mathrm{g} /$ $\mathrm{ml})$ from min 40 to $46(\bullet, \mathrm{n}=11)$. Compared to control experiments $(\boldsymbol{\Delta}, \mathrm{n}=6)$ zymosan increased PPP transiently by about by $400 \%(* \mathrm{p}<0.05)$. The additional inhibition of NOS by L-NAME $(0.3 \mathrm{mM}$, min 30-100) markedly enhanced this increase of PPP $\left(\triangle, \mathrm{n}=5,{ }^{\#} \mathrm{p}<0.05\right)$. b The augmented increase of PPP by LNAME $\left(0.3 \mathrm{~mm}, \min 30-100,{ }^{+} \mathrm{p}<0.05, \mathrm{n}=5\right)$ was reduced by

\section{Drugs and Reagents}

Zymosan, indomethacin and dimethyl sulfoxide were obtained from Sigma Chemical Co. (St. Louis, Mo., USA). NS-2028, 8-Br-cGMP and L-NAME were obtained from Calbiochem (Bad Soden, Germany). Zymosan was suspended directly in perfusion buffer. All other reagents were prepared as aqueous stock solutions (L-NAME) or DMSO stock solutions (NS-2028, 8-Br-cGMP, indomethacin). Stock solutions were infused into the portal inflow of the perfusion system by microinfusion pumps at a rate of $50 \mu \mathrm{l} / \mathrm{min}$.

\section{Statistics}

All data are expressed as mean \pm SD. Statistical analyses of data were performed using a Mann-Whitney U test. $\mathrm{p}<0.05$ was considered statistically significant.

\section{Results}

\section{NO, GC and cGMP Pathway}

The free radical NO is a well-known vasodilator. In the first part of the study the effects of NO on PP following $\mathrm{KC}$ activation were studied. The $\beta$-glycan-rich zymosan was infused to activate KCs. The PPP increased about $400 \%$ following zymosan infusion (fig. 1a). In control

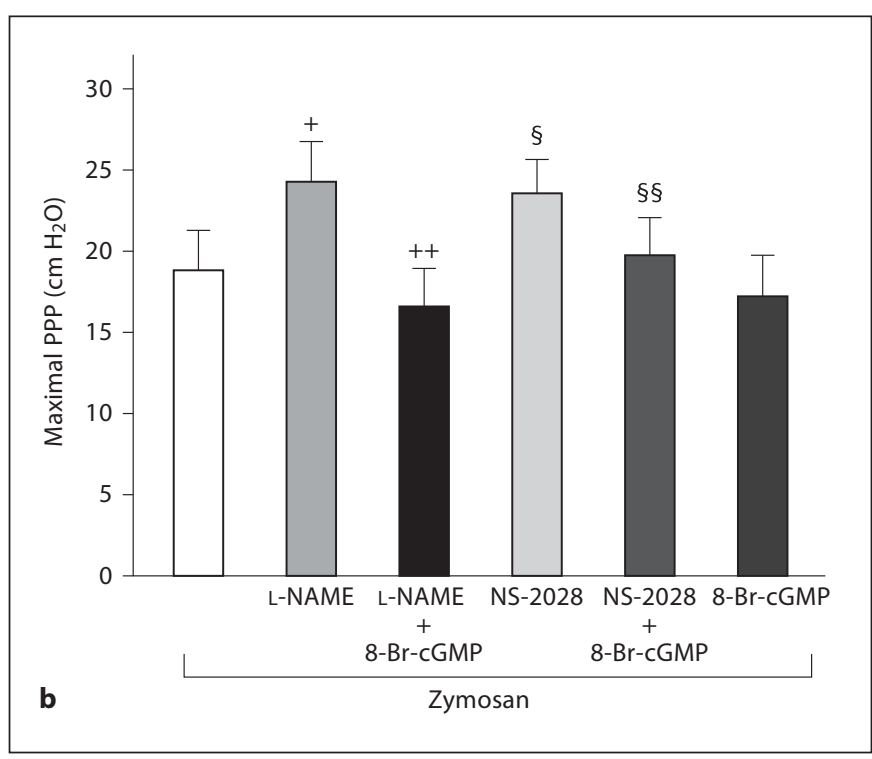

infusion of the cGMP analogue 8-Br-cGMP $(50 \mu \mathrm{M}$, min 30-100, $\left.{ }^{++} \mathrm{p}<0.05, \mathrm{n}=5\right)$. Inhibition of the GC by NS-2028 $(1.0 \mu \mathrm{M}, \mathrm{min}$ $30-100,{ }^{\S} \mathrm{p}<0.05, \mathrm{n}=5$ ) markedly increased the PPP which was again reduced by addition of 8 -Br-cGMP $(50 \mu \mathrm{M}$, min 30-100, $\$ \S \mathrm{p}<0.05, \mathrm{n}=5)$. Infusion of 8-Br-cGMP $(50 \mu \mathrm{M}, \min 30-100$, $\mathrm{n}=5$ ) did not lower the increase of PPP following zymosan infusion $(150 \mu \mathrm{g} / \mathrm{ml}$, min $40-46, \mathrm{n}=11)$.

perfusion experiments the PPP did not change over 100 min (fig. 1a). Inhibition of the NOS by L-NAME increased the maximal PPP to a higher degree than the KC activation by zymosan alone (fig. 1a). The maximal PPP following zymosan and L-NAME infusion was diminished by the cGMP analogue 8-Br-cGMP (fig. 1b). The maximal PPP was also enhanced by inhibition of the soluble GC by NS-2028 (fig. 1b). Again, the infusion of 8-Br-cGMP reduced the maximal PPP following the combined administration of zymosan A and NS-2028 (fig. 1b). In contrast, infusion of 8-Br-cGMP had almost no effect on PPP following $\mathrm{KC}$ activation (fig. 1b).

\section{Prolonged Increase of PPP by Inhibition of $\mathrm{HO}$}

The concomitant inhibition of HO by zinc protoporphyrin IX (ZnPP IX) resulted in a massive and prolonged increase of PPP compared to the PPP increase caused by the infusion of zymosan alone (fig. 2a). In contrast, the infusion of ZnPP IX alone increased the PPP only slightly (fig. 2a). The additional administration of $\mathrm{CO}$ following $\mathrm{KC}$ activation and inhibition of $\mathrm{HO}$ lowered the PPP during the time period from 60 to $100 \mathrm{~min}$ of perfusion time (fig. 2b). Interestingly, this 


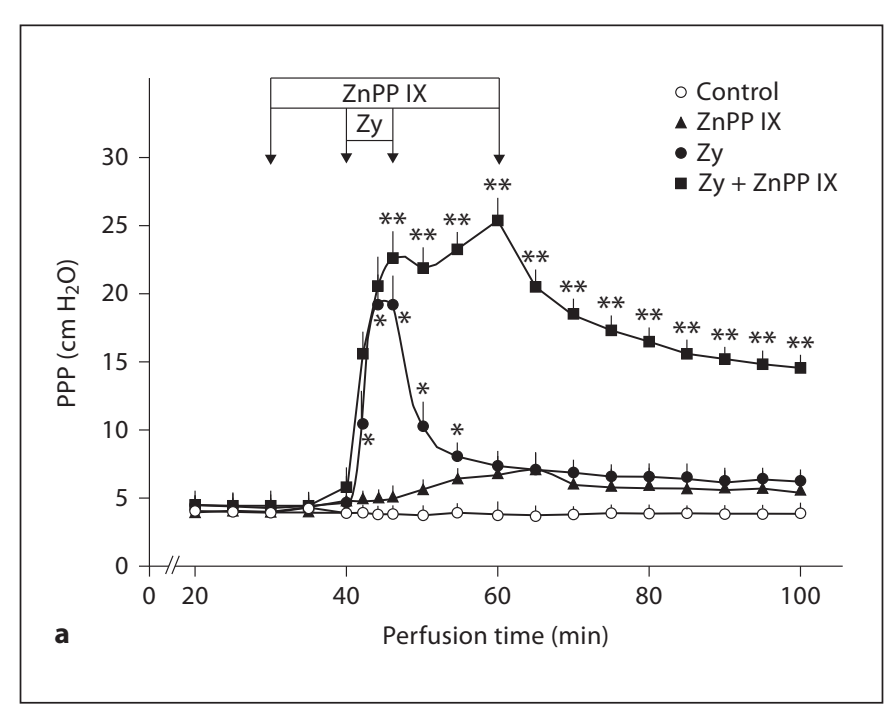

Fig. 2. Prolonged increase of PPP following KC activation and inhibition of the HO by ZnPP IX. a Activation of KCs by zymosan (Zy) $(\bullet, 150 \mu \mathrm{g} / \mathrm{ml}, \min 40-46)$ increased the PPP $\left({ }^{*} \mathrm{p}<0.05\right.$, $\mathrm{n}=11)$ compared to control experiments $(O, \mathrm{n}=6)$. Inhibition of $\mathrm{HO}$ by ZnPP IX $(1 \mu \mathrm{M}$, min 30-60) in addition to KC activation ( $\mathbf{\square}$, zymosan $150 \mu \mathrm{g} / \mathrm{ml}$, min $40-46, \mathrm{n}=5$ ) increased the PPP to a higher maximum compared to the infusion of zymosan alone $\left({ }^{* *} \mathrm{p}<0.05\right)$. Additionally, the PPP was elevated until end of experiments $\left({ }^{* *} \mathrm{p}<0.05\right)$. The infusion of $\operatorname{ZnPP} \operatorname{IX}(\boldsymbol{\Delta}, 1 \mu \mathrm{M}$, min $30-60, n=5)$ increased the PPP slightly over control values $(\bigcirc$, $\mathrm{n}=6) \cdot \mathbf{b}$ The infusion of ZnPP IX $(1 \mu \mathrm{M}$, min 30-100) in addition to $\mathrm{KC}$ activation by zymosan $(150 \mu \mathrm{g} / \mathrm{ml}, \min 40-46)([2], \mathrm{n}=5)$

effect was not cGMP-dependent, because the infusion of 8-Br-cGMP instead of CO had almost no effect on the PPP (fig. 2b).

\section{Enhanced PG Production by KC Activation and Inhibition of $\mathrm{HO}$}

The activation of KCs by zymosan resulted in a transient increase of the formation of $\mathrm{PGD}_{2}, \mathrm{PGF}_{2} \alpha$ and $\mathrm{TXB}_{2}$, the stable degradation product of TXA 2 (fig. $3 \mathrm{a}-\mathrm{c}$ ). In parallel to the increase of PPP the formation of the $\mathrm{PGD}_{2}, \mathrm{PGF}_{2} \alpha$ and $\mathrm{TXB}_{2}$ were enhanced by the inhibition of $\mathrm{HO}$ up from min 46 until the end of the experiments (fig. 3a-c).

\section{Functional Role of the Increased PG Production}

To address the functional role of the increased PG and $\mathrm{TXB}_{2}$ efflux rates following $\mathrm{KC}$ activation and $\mathrm{HO}$ inhibition, the COX inhibitor indomethacin was additionally infused. Indomethacin, a simultaneous COX-1 and COX2 inhibitor, reduced the profound hemodynamic effects by $\mathrm{HO}$ inhibition and $\mathrm{KC}$ activation (fig. 4).

Heme Oxygenases and Prostaglandin Formation

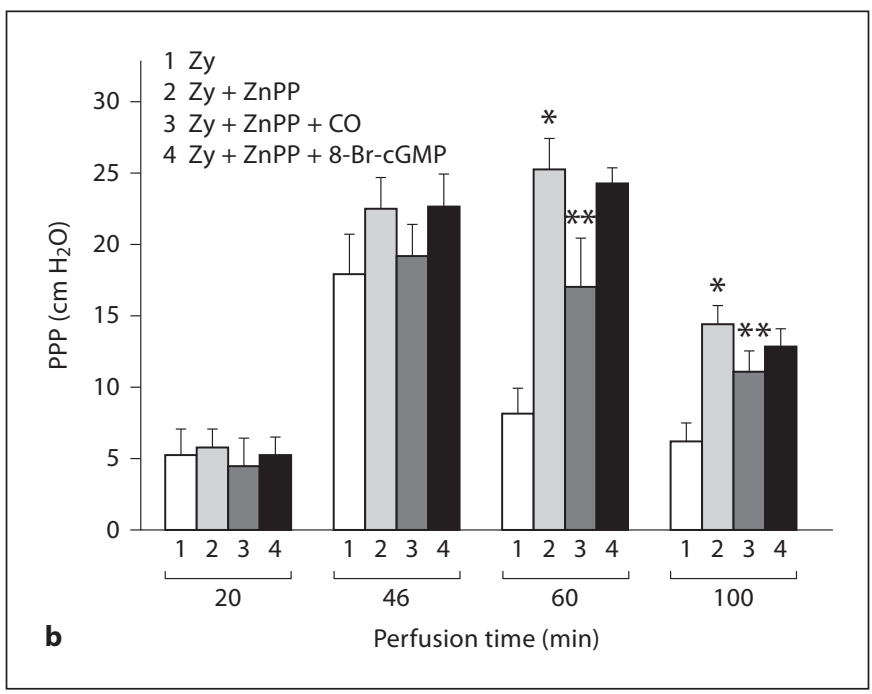

increased the PPP significantly $\left({ }^{*} \mathrm{p}<0.05\right)$ compared to the infusion of zymosan ([1], $150 \mu \mathrm{g} / \mathrm{ml}$, min $40-46, \mathrm{n}=11)$. The infusion of CO ([3], $2.5 \mu \mathrm{M}, \min 30-100, \mathrm{n}=5)$ together with $\mathrm{KC}$ activation by zymosan $(150 \mu \mathrm{g} / \mathrm{ml}, \min 40-46, \mathrm{n}=5)$ and $\mathrm{HO}$ inhibition by ZnPP IX infusion $(1 \mu \mathrm{M}$, min $30-100, \mathrm{n}=5)$ reduced significantly $\left({ }^{* *} \mathrm{p}<0.05\right)$ the PPP increase compared to the simultaneous infusion of zymosan $(150 \mu \mathrm{g} / \mathrm{ml}$, min $40-46)$ and ZnPP IX $(1 \mu \mathrm{M}$, min 30-100) ([2], $\mathrm{n}=5)$. In contrast, the infusion of the cGMP analogue 8-Br-CGMP ([4], $50 \mu \mathrm{M}, \min 30-100, \mathrm{n}=5$ ) did not lower the PPP compared to the combination of KC activation (zymosan $150 \mu \mathrm{g} / \mathrm{ml}$, min 40-46) and inhibition of HO (ZnPP IX $1 \mu \mathrm{M}, \min 30-100)([2], \mathrm{n}=5)$.

\section{Discussion}

This study describes a novel mechanism of PP increase in normal livers by inhibition of HO. There were three principal findings of our study: (1) the inhibition of the NOS increased the PPP cGMP dependently; (2) the inhibition of $\mathrm{HO}$ extended the PPP increase from transient to long-lasting following $\mathrm{KC}$ activation, and (3) the effect of $\mathrm{HO}$ was CGMP-independent but based on the increased production of $\mathrm{PGs}$ and $\mathrm{TXB}_{2}$.

\section{$N O$ and $G C s$}

In the first part of this study we investigated the GC NO pathway and its potential role to counteract the increase of PPP following KC activation in normal livers. The inhibition of the intrahepatic NO formation by LNAME as well as the inhibition of the GC by NS-2028 enhanced the increase of PPP following KC activation. These additional PPP increases were abolished by the cGMP analogue 8-Br-cGMP in both settings. Cells with contractile potential are mainly the hepatic stellate cells 


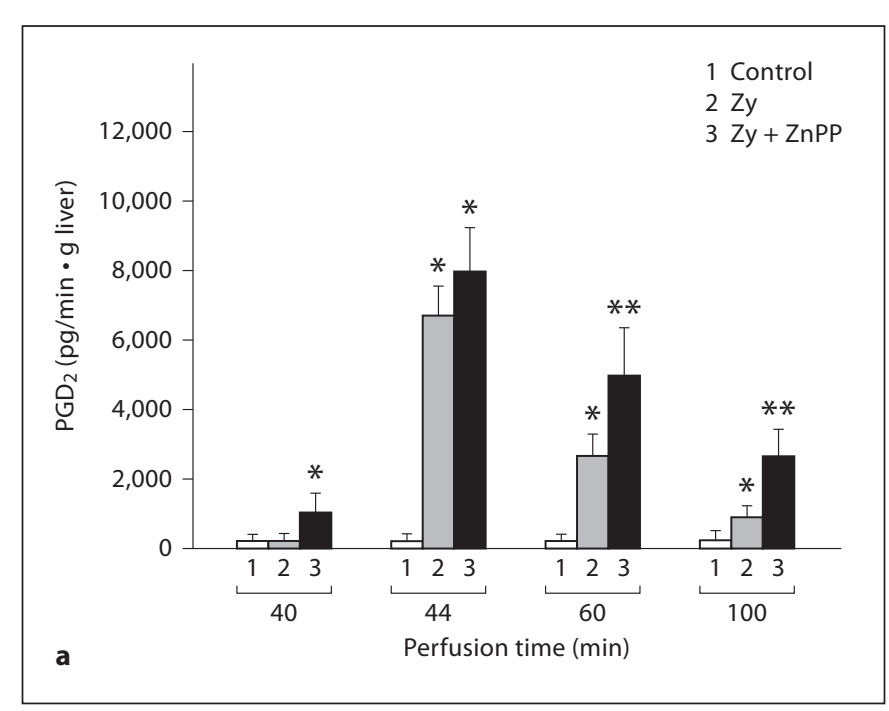

Fig. 3. Control of PG formation by HO. Increase of the PPP following KC activation (zymosan (Zy) $150 \mu \mathrm{g} / \mathrm{ml}$, min 40-46) was paralleled by an augmented PG efflux. This efflux was further enhanced by the additional inhibition of the HO by ZnPP IX (1 $\mu \mathrm{M}$, min 30-100, each $\mathrm{n}=5$ ): (a) $\mathrm{PGD}_{2}$ efflux (control [1] vs. zymosan $150 \mu \mathrm{g} / \mathrm{ml}$, min 40-46 [2] vs. zymosan $150 \mu \mathrm{g} / \mathrm{ml}$, min 40-46 and ZnPP IX $1 \mu \mathrm{M}, \min 30-100$ [3], $\left.{ }^{*} \mathrm{p}<0.05,{ }^{* *} \mathrm{p}<0.05\right)$, (b) $\mathrm{PGF}_{2} \alpha$ efflux (control [1] vs. zymosan $150 \mu \mathrm{g} / \mathrm{ml}$, min $40-46$ [2] vs. zymosan $150 \mu \mathrm{g} / \mathrm{ml}$, min 40-46 and ZnPP IX $1 \mu \mathrm{M}$, min 30-100 [3], ${ }^{*} \mathrm{p}<0.05,{ }^{* *} \mathrm{p}<0.05$ ), and (c) $\mathrm{TXB}_{2}$ efflux (control [1] vs. zymosan $150 \mu \mathrm{g} / \mathrm{ml}$, min 40-46 m [2] vs. zymosan $150 \mu \mathrm{g} / \mathrm{ml}$, min 40-46 and ZnPP IX $1 \mu \mathrm{M}, \min 30-100$ [3], ${ }^{*} \mathrm{p}<0.05,{ }^{* *} \mathrm{p}<$ 0.05).

and the myofibroblasts. Both cell types have been described previously to mediate contraction of the hepatic microvasculature NO dependently $[18,26,27]$. Furthermore, effects of NO on contractile cells are cGMP-mediated, which could explain the observed cGMP effects in the present study [36]. Additionally, liver sinusoidal endothelial cells have been described to play an important role for the NO pathway $[28,29,37]$; however, the interaction of all non-parenchymal cell types in sinusoidal blood flow regulation has not yet been understood in detail. Hypothetically the imbalance of vasoconstrictors and vasodilators in liver injury is not related to one of the cell types but to the interplay of all non-parenchymal cell types. It seems of major interest for future studies to compare the vasoconstrictive and vasodilative potential of each cell type.
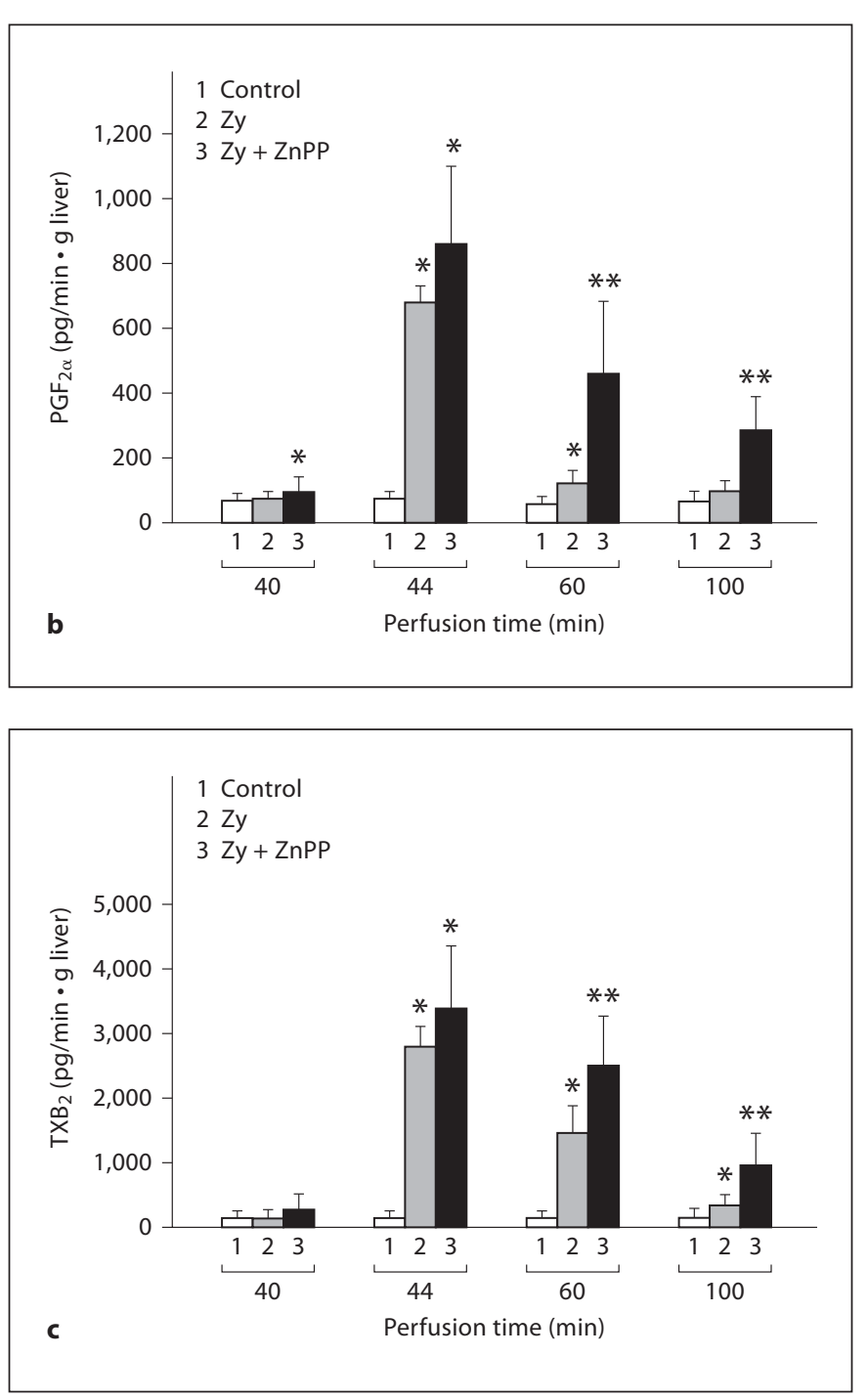

\section{$\mathrm{HO}$ and $\mathrm{CO}$}

In the second part of this study we investigated the $\mathrm{HO}-\mathrm{CO}$ pathway. We demonstrated that the inhibition of $\mathrm{HO}$ in combination with $\mathrm{KC}$ activation increased the PPP. KCs and $\mathrm{HO}$ have been described to play a major role in many liver diseases like acute liver failure [38-40] and ischemia-reperfusion injury [41]. The hemodynamic effects of $\mathrm{HO}$ following $\mathrm{KC}$ activation have however not been investigated up to now. We have studied the mechanisms increasing PP in normal and fibrotic livers before following $\mathrm{KC}$ activation [5]. Interestingly, the transient PPP increase following $\mathrm{KC}$ activation was prolonged by the additional inhibition of $\mathrm{HO}$. Inhibition of $\mathrm{HO}$ alone increased the PPP only slightly as it has been described in a previous study [21]. The PPP effects observed in the 


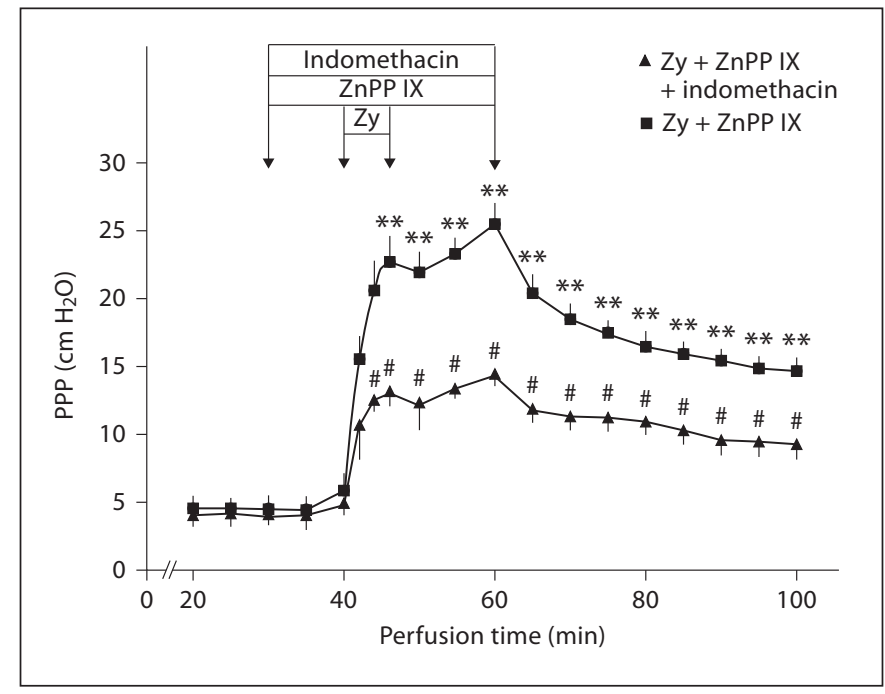

Fig. 4. Functional relevance of the enhanced amount of PGs in the effluent perfusate. The COX inhibitor indomethacin $(\boldsymbol{\Lambda}, 50 \mu \mathrm{M}$, $\min 30-60, \mathrm{n}=5)$ reduced $\left({ }^{*} \mathrm{p}<0.05,{ }^{* *} \mathrm{p}<0.05\right)$ the increase of PPP following zymosan (Zy) infusion (150 $\mu \mathrm{g} / \mathrm{ml}$, min $40-46)$ and additional administration of $\operatorname{ZnPP} \operatorname{IX}(\boldsymbol{\square}, 1 \mu \mathrm{M}, \min 30-100$, $\mathrm{n}=5)$.

present study can therefore not be the result of the simple addition of both PPP increases, resulting from zymosan infusion alone or ZnPP IX infusion alone.

In the next step we investigated the involved mechanisms. The vasodilator $\mathrm{CO}$ is produced by the degradation from heme to biliverdin. Indeed, infusion of $\mathrm{CO}$ attenuated the PPP increase by about $40 \%$, but this effect was not dependent on cGMP. The lack of effect is not due to a low concentration, because the same concentration of $8-\mathrm{Br}-\mathrm{cGMP}$ was already used in the experiments with NO described above in the present study. Interestingly, the efflux of the $\mathrm{PGD}_{2}$ and $\mathrm{PGF}_{2} \alpha$ and the $\mathrm{TXA}_{2}$ were enhanced by the inhibition of the $\mathrm{HO}$ in combination with KC activation. The functional role of the increased PG production was investigated by indomethacin, a combined COX-1 and COX-2 inhibitor. The additional infusion of indomethacin attenuated the PPP increase about $60 \%$. Heme is an apoenzyme of COX [42]. Therefore, high concentrations of heme imply high activity of COX. Inhibition of $\mathrm{HO}$ therefore leads to high amounts of heme and consecutively high activity of COX. This could explain the increase of the PG efflux and the increase of the PPP following $\mathrm{KC}$ activation and $\mathrm{HO}$ inhibition.
Another relevant aspect concerning the protective effects of $\mathrm{HO}$ and $\mathrm{CO}$ could be the antioxidative property of CO [43]. Reactive oxygen species play an important role in ischemia/reperfusion injury [34] and in acute liver injury. This might on the one side activate hepatic stellate cells and on the other side impair endothelial dysfunction. Protective effects of $\mathrm{CO}$ in the present study might therefore additionally be related to its antioxidative property, but this was not investigated more in detail in the present study.

The HO pathway is also known to play an important role in fibrogenesis, liver fibrosis and liver cirrhosis. Recently it has been shown in Mdr2 knockout mice that induction of HO-1 was able to revert portal inflammation and fibrosis [44]. Furthermore, earlier studies demonstrated the role of $\mathrm{HO}$ and $\mathrm{CO}$ in the regulation of intrahepatic resistance in cirrhotic rat livers [24]. The role of KCs was not investigated in this earlier study but it could be hypothesized that the counteracting mechanism of $\mathrm{HO}$ and $\mathrm{CO}$ production is also of relevance in cirrhotic livers following $\mathrm{KC}$ activation.

\section{Clinical Implications of This Study}

This study describes novel mechanisms of counteraction of PP increase in normal livers following KC activation. Situations of KC activation in the clinical context are conceivable in each situation of an increased load in the portal vein of TLR agonists like bacterial or fungal products. Clinical examples are ischemia-reperfusion with increased amounts of pathogen-associated molecular patterns, biliary obstruction with cholangitis and sepsis. Microcirculatory disturbances are observed as shown by the present study immediately after the exposure to the TLR2 and TLR- 9 agonist zymosan. Interestingly, mechanisms of counteraction started almost simultaneously. To know the counteracting mechanisms seems of clinical relevance for potentially new therapeutic strategies. For example, induction of $\mathrm{HO}$ seems feasible in the near future as a therapeutic intervention.

In conclusion, our results show that in normal livers following $\mathrm{KC}$ activation there is a role for $\mathrm{NO}$ and for $\mathrm{HO}$ to influence PPP. We found that NO acts via GC and cGMP as a vasodilating mechanism following KC activation. In contrast, CO does not act via cGMP. The inhibition of the HO led to an increased PG and TX formation following KC activation, which led to a prolonged PPP increase. In the context of $\mathrm{KC}$ activation, $\mathrm{HO}$ are important regulators of liver hemodynamics. This knowledge can be considered for future therapeutical strategies like induction of $\mathrm{HO}$. 


\section{References}

$>1$ Eguchi H, McCuskey PA, McCuskey RS: Kupffer cell activity and hepatic microvascular events after acute ethanol ingestion in mice. Hepatology 1991;13:751-757.

$>2$ Miller AM, Masrorpour M, Klaus C, Zhang JX: LPS exacerbates endothelin-1 induced activation of cytosolic phospholipase $\mathrm{A}_{2}$ and thromboxane $\mathrm{A}_{2}$ production from Kupffer cells of the prefibrotic rat liver. J Hepatol 2007;46:276-285.

3 Lee CH, Loureiro-Silva MR, Abraldes JG, Iwakiri Y, Haq O, Groszmann RJ: Decreased intrahepatic response to $\alpha_{1}$-adrenergic agonists in lipopolysaccharide-treated rats is located in the sinusoidal area and depends on Kupffer cell function. J Gastroenterol Hepatol 2007;22:893-900.

4 Bilzer M, Roggel F, Gerbes AL: Role of Kupffer cells in host defense and liver disease. Liver Int 2006;26:1175-1186.

$>5$ Steib CJ, Gerbes AL, Bystron M, Op den Winkel M, Hartl J, Roggel F, Prufer T, Goke B, Bilzer M: Kupffer cell activation in normal and fibrotic livers increases portal pressure via thromboxane $\mathrm{A}_{2}$. J Hepatol 2007;47:228238.

$\checkmark 6$ Steib CJ, Hartmann AC, von Hesler C, Benesic A, Hennenberg M, Bilzer M, Gerbes AL: Intraperitoneal LPS amplifies portal hypertension in rat liver fibrosis. Lab Invest 2010; 90:1024-1032.

7 Steib CJ: Signaling pathways in liver diseases: Kupffer cells; in Dufour J-F, Clavien P-A (eds): Signaling Pathways in Liver Diseases. Heidelberg, Springer, 2010, pp 69-78.

$>8$ Titos E, Claria J, Bataller R, Bosch-Marce M, Gines P, Jimenez W, Arroyo V, Rivera F, Rodes J: Hepatocyte-derived cysteinyl leukotrienes modulate vascular tone in experimental cirrhosis. Gastroenterology 2000; 119:794-805.

$>9$ Graupera M, Garcia-Pagan JC, Titos E, Claria J, Massaguer A, Bosch J, Rodes J: 5-Lipoxygenase inhibition reduces intrahepatic vascular resistance of cirrhotic rat livers: a possible role of cysteinyl-leukotrienes. Gastroenterology 2002;122:387-393.

10 Graupera M, Garcia-Pagan JC, Abraldes JG, Peralta C, Bragulat M, Corominola H, Bosch J, Rodes J: Cyclooxygenase-derived products modulate the increased intrahepatic resistance of cirrhotic rat livers. Hepatology 2003; 37:172-181.

-11 Steib CJ, Bilzer M, op den Winkel M, Pfeiler S, Hartmann AC, Hennenberg M, Goke B, Gerbes AL: Treatment with the leukotriene inhibitor montelukast for 10 days attenuates portal hypertension in rat liver cirrhosis. Hepatology 2010;51:2086-2096.

$\checkmark 12$ Steib CJ, Hennenberg M, Beitinger F, Hartmann AC, Bystron M, De Toni EN, Gerbes AL: Amiloride reduces portal hypertension in rat liver cirrhosis. Gut 2010;59:827-836.
13 Zhou Q, Hennenberg M, Trebicka J, Jochem K, Leifeld L, Biecker E, Sauerbruch T, Heller $\mathrm{J}$ : Intrahepatic upregulation of RhoA and Rho-kinase signalling contributes to increased hepatic vascular resistance in rats with secondary biliary cirrhosis. Gut 2006; 55:1296-1305.

14 Trebicka J, Hennenberg M, Schulze Probsting A, Laleman W, Klein S, Granzow M, Nevens F, Zaagsma J, Heller J, Sauerbruch T: Role of $\beta_{3}$-adrenoceptors for intrahepatic resistance and portal hypertension in liver cirrhosis. Hepatology 2009;50:1924-1935.

15 Hennenberg M, Trebicka J, Kohistani Z, Stark C, Nischalke HD, Kramer B, Korner C, Klein S, Granzow M, Fischer HP, Heller J, Sauerbruch T: Hepatic and HSC-specific sorafenib effects in rats with established secondary biliary cirrhosis. Lab Invest 2011;91: 241-251.

16 Shah V, Toruner M, Haddad F, Cadelina G, Papapetropoulos A, Choo K, Sessa WC, Groszmann RJ: Impaired endothelial nitric oxide synthase activity associated with enhanced caveolin binding in experimental cirrhosis in the rat. Gastroenterology 1999; 117:1222-1228.

17 Shah V, Wiest R, Garcia-Cardena G, Cadelina G, Groszmann RJ, Sessa WC: Hsp90 regulation of endothelial nitric oxide synthase contributes to vascular control in portal hypertension. Am J Physiol 1999;277:G463G468.

18 Wiest R, Shah V, Sessa WC, Groszmann RJ: No overproduction by eNOS precedes hyperdynamic splanchnic circulation in portal hypertensive rats. Am J Physiol 1999; 276:G1043-G1051.

19 Shah V, Chen AF, Cao S, Hendrickson H, Weiler D, Smith L, Yao J, Katusic ZS: Gene transfer of recombinant endothelial nitric oxide synthase to liver in vivo and in vitro. Am J Physiol Gastrointest Liver Physiol 2000;279:G1023-G1030.

20 Fiorucci S, Antonelli E, Mencarelli A, Orlandi S, Renga B, Rizzo G, Distrutti E, Shah V, Morelli A: The third gas: $\mathrm{H} 2$ s regulates perfusion pressure in both the isolated and perfused normal rat liver and in cirrhosis. Hepatology 2005;42:539-548.

-21 Suematsu M, Goda N, Sano T, Kashiwagi S, Egawa T, Shinoda Y, Ishimura Y: Carbon monoxide: an endogenous modulator of sinusoidal tone in the perfused rat liver. J Clin Invest 1995;96:2431-2437.

22 Wakabayashi Y, Takamiya R, Mizuki A, Kyokane T, Goda N, Yamaguchi T, Takeoka S, Tsuchida E, Suematsu M, Ishimura Y: Carbon monoxide overproduced by heme oxygenase-1 causes a reduction of vascular resis tance in perfused rat liver. Am J Physiol 1999; 277:G1088-G1096.
23 Matei V, Rodriguez-Vilarrupla A, Deulofeu R, Colomer D, Fernandez M, Bosch J, GarciaPagan JC: The eNOS cofactor tetrahydrobiopterin improves endothelial dysfunction in livers of rats with $\mathrm{CCl} 4$ cirrhosis. Hepatology 2006;44:44-52.

24 Van Landeghem L, Laleman W, Vander Elst I, Zeegers M, van Pelt J, Cassiman D, Nevens F: Carbon monoxide produced by intrasinusoidally located haem-oxygenase-1 regulates the vascular tone in cirrhotic rat liver. Liver Int 2009;29:650-660.

-25 Gracia-Sancho J, Russo L, Garcia-Caldero H, Garcia-Pagan JC, Garcia-Cardena G, Bosch $\mathrm{J}$ : Endothelial expression of transcription factor Kruppel-like factor 2 and its vasoprotective target genes in the normal and cirrhotic rat liver. Gut 2011;60:517-524.

-26 Trebicka J, Hennenberg M, Laleman W, Shelest N, Biecker E, Schepke M, Nevens F, Sauerbruch T, Heller J: Atorvastatin lowers portal pressure in cirrhotic rats by inhibition of RhoA/Rho-kinase and activation of endothelial nitric oxide synthase. Hepatology 2007;46:242-253.

27 Laleman W, Van Landeghem L, Severi T, Vander Elst I, Zeegers M, Bisschops R, Van Pelt J, Roskams T, Cassiman D, Fevery J, Nevens F: Both $\mathrm{Ca}^{2+}$-dependent and -independent pathways are involved in rat hepatic stellate cell contraction and intrahepatic hyperresponsiveness to methoxamine. Am J Physiol Gastrointest Liver Physiol 2007; 292:G556-G564.

28 Shah V, Haddad FG, Garcia-Cardena G, Frangos JA, Mennone A, Groszmann RJ, Sessa WC: Liver sinusoidal endothelial cells are responsible for nitric oxide modulation of resistance in the hepatic sinusoids. J Clin Invest 1997; 100:2923-2930.

29 Gupta TK, Toruner M, Chung MK, Groszmann RJ: Endothelial dysfunction and decreased production of nitric oxide in the intrahepatic microcirculation of cirrhotic rats. Hepatology 1998;28:926-931.

30 Kelly DM, Shiba H, Nakagawa S, Irefin S, Eghtesad B, Quintini C, Aucejo F, Hashimoto K, Fung JJ, Miller C: Hepatic blood flow plays an important role in ischemia-reperfusion injury. Liver Transpl 2011;17:1448-1456.

-31 Ito Y, Abril ER, Bethea NW, McCuskey RS: Role of nitric oxide in hepatic microvascular injury elicited by acetaminophen in mice. Am J Physiol Gastrointest Liver Physiol 2004;286:G60-G67.

32 Li X, Klintman D, Liu Q, Sato T, Jeppsson B, Thorlacius H: Critical role of CXC chemokines in endotoxemic liver injury in mice. J Leukoc Biol 2004;75:443-452.

33 Eipel C, Bordel R, Nickels RM, Menger MD, Vollmar B: Impact of leukocytes and platelets in mediating hepatocyte apoptosis in a rat model of systemic endotoxemia. Am J Physiol Gastrointest Liver Physiol 2004; 286:G769-G776. 
34 Bilzer M, Baron A, Schauer R, Steib C, Ebensberger S, Gerbes AL: Glutathione treatment protects the rat liver against injury after warm ischemia and Kupffer cell activation. Digestion 2002;66:49-57.

35 Wang R, Wang Z, Wu L: Carbon monoxideinduced vasorelaxation and the underlying mechanisms. Br J Pharmacol 1997; 121:927934.

36 Reynaert $\mathrm{H}$, Thompson MG, Thomas T, Geerts A: Hepatic stellate cells: role in microcirculation and pathophysiology of portal hypertension. Gut 2002;50:571-581.

37 Marrone G, Russo L, Rosado E, Hide D, Garcia-Cardena G, Garcia-Pagan JC, Bosch J, Gracia-Sancho J: The transcription factor KLF2 mediates hepatic endothelial protection and paracrine endothelial-stellate cell deactivation induced by statins. J Hepatol 2012, E-pub ahead of print.
8 Gehring S, Dickson EM, San Martin ME, van Rooijen N, Papa EF, Harty MW, Tracy TF Jr, Gregory SH: Kupffer cells abrogate cholestatic liver injury in mice. Gastroenterology 2006;130:810-822.

39 Schumann J, Wolf D, Pahl A, Brune K, Papadopoulos T, van Rooijen N, Tiegs G: Importance of Kupffer cells for T-cell-dependent liver injury in mice. Am J Pathol 2000;157: 1671-1683.

40 Angermayr B, Mejias M, Gracia-Sancho J, Garcia-Pagan JC, Bosch J, Fernandez M: Heme oxygenase attenuates oxidative stress and inflammation, and increases VEGF expression in portal hypertensive rats. J Hepatol 2006;44:1033-1039.

41 Jaeschke H: Mechanisms of liver injury. II. Mechanisms of neutrophil-induced liver cell injury during hepatic ischemia-reperfusion and other acute inflammatory conditions. Am J Physiol Gastrointest Liver Physiol 2006;290:G1083-G1088.
42 Haider A, Olszanecki R, Gryglewski R, Schwartzman ML, Lianos E, Kappas A, Nasjletti A, Abraham NG: Regulation of cyclooxygenase by the heme-heme oxygenase system in microvessel endothelial cells. J Pharmacol Exp Ther 2002;300:188-194

43 Brugger J, Schick MA, Brock RW, Baumann A, Muellenbach RM, Roewer N, Wunder C: Carbon monoxide has antioxidative properties in the liver involving p38 MAP kinase pathway in a murine model of systemic inflammation. Microcirculation 2010;17:504513.

44 Barikbin R, Neureiter D, Wirth J, Erhardt A, Schwinge D, Kluwe J, Schramm C, Tiegs G, Sass G: Induction of heme oxygenase-1 prevents progression of liver fibrosis in Mdr2 knockout mice. Hepatology 2012;55:553562 